\title{
SSinteza
}

Impact of Internet on Business Activities in Serbia and Worldwide

Uticaj Interneta na poslovanje u Srbiji i svetu

DOI:

10.15308/SINTEZA-2014-1020-1022

\section{PRIKRIVENI MARKETING}

\author{
Branislav R. Tanasić \\ Ministarstvo finansija - Carina, Beograd
}

\begin{abstract}
:
Propagandna Internet kampanja koja ima za cilj da generiše prikrivene forme reklamiranja, ekonomična je, jednom pokrenuta u dovoljnoj količini, biva gotovo besplatna, postaje preporuka koja se kroz mrežu sve više širi. Skriveni marketing može da dopre do potrošača koji su izolovani od ostalih medija, i za razliku od njih, potrošači imaju tendenciju da više veruju u ovako plasirane sadržaje. Kada se za ciljnu grupu zna da će biti dosledni korisnici Interneta, stealth marketari imaju značajan interes da koriste chat rooms, Face book, razne blog sajtove i društvene forume. $U$ ovim podešavanjima ljudi imaju tendencije da se medjusobno doživljavaju kao ravnopravni. Anonimnost redukuje rizik otkrivanja, tako da jedan marketar može izvršiti uticaj na veći broj ljudi. Za vreme dot.com buma, na prelazu u novi vek, promoteri često koriste društvene mreže za kreiranje buzz (stealth) marketinga. Istina je da marketari teško mogu predvideti pravce razvoja buzz propagande. Dobro plasirana, jednom pokrenuta, medju potrišačima će početi da se prenosi priča dalje, poput verbalne tehnike od usta do usta, inicirajući tako planiranu virusnu marketing kampanju, koja će da raste spontano. Finansijski rizik gotovo da ne postoji jer su troškovi izuzetno niski, i obično se veoma brzo i višestruko isplate. Prikriveni marketing se koristi kada su tradicionalne tehnike iscrpljene, ili se reklamira proizvod kome su uobičajeni propagandni tokovi nedostupni. Ovo ostaje jeftin, efikasan način za generisanje prikrivenog marketinga, naročito za tržište kao što je duvan i alkohol, gde su mediji, u cilju zaštite potrošača, nedostupni kao forma oglašavanja.
\end{abstract}

\author{
Key words: \\ Internet, \\ propaganda, \\ prikriveni marketing, \\ stealth (buzz).
}

\section{UVOD}

On - line reklamiranje ili Internet advertising, koristi Internet za isporučivanje promotivnih marketinških poruka potencijalnim potrošačima. Ova aktivnost može da se ostvari upotrebom E - mail, Web pretraživača, Web Baner, raznih društvenih foruma ali i upotrebom mreže mobilne telefonije.

Internet marketing je posao velikog obima i ubrzano raste. Samo u SAD prihodi od on- line oglašavanja, premašuju zaradu kablovske televizije, tako da je u 2012. godini ostvareno 36,6 milijardi dolara, što predstavlja povećanje od 15,2\% u odnosu na 2011. godinu. [1]

Provedeno istraživanje, studija praćenja vidnog polja (kretanja očiju - Eye tracking studies) pokazuje da Internet korisnici zanemaruju zone na Web stranici koje pokazuju dodatke, obično neki propagandni sadržaj. Ova pojava se naziva " baner blidness " $i$ ignorisanje je izraženije na on- line medijima nega kod štampanih izdanja. Sa druge strane studija sugeriše da ovaj sadržaj (misli se na promotivni dodatak), može imati značajan uticaj na podsvest posmatrača. [2]
Internet je drastično izmenio način na koji se informacije distribuiraju i imao je značajan uticaj na marketing. Zadnjih nekoliko godina, uvedeno je u proceduru više novih marketinških tehnika, zbog kojih su neki pristupi marketingu postali antikviteti.

Cambridge Business English Dictionary tumači prikriveni - Stealth marketing kao propagiranje proizvoda na takav način da ljudi nisu svesni da ustvari, pokušavate da ih ubedite da proizvod kupe.

Stealth je termin koji se koristi u viralnom marketingu, $i$ to je interakcija potrošača i korisnika proizvoda i usluga u cilju pojačavanja originalne marketinške poruke. [3]

\section{BUZZ MARKETING}

Smatra se da savremeni čovek, tokom prosečnog života, biva izložen preko 2 miliona puta razno - raznim reklamnim porukama. Pre samo tridesetak godina, ljudi su bili u stanju da pamte i do $30 \%$ vidjenog. Prezasićenje ovim porukama aktivira odbrambene mehanizme, mozak selektuje i filtrira sadžaje, tako da čovek današnjice jedva memoriše dve reklame, od ukupno vidjenih! [4] 
Ovu situaciju marketari prevazilaze pribegavajući uglavnom jednom od dva rešenja:

- Još agresivnijom reklamom, koja se sadržajem i stilom izdvaja od drugih, i na taj način pokušavaju da se nametnu i skrenu pažnju na svoju ponudu.

- Drugi način su prikriveni oglasi, transformisani u neke druge sadržaje, i obično, asocijativnim vezama šalje se poruka, često daleko delotvornija od one direktne.

Uopšte, Stealth oglašavanjem smatraju se oni sadržaji koji nisu direktno uoćljivi, ali posredno ili čak subliminalno, nose odredjene poruke. Ovi sadržaji mogu biti plasirani u rasponu od običnog teksta koji u superlativima opisuje neku firmu, ili odredjeni proizvod, pa do sofisticiranih poruka koje vešto plasirane, nose snažnu asocijaciju na proizvod odnosno brend.

Suština je u načinu dejstva izloženog teksta: čitalac pristupa sadržaju ubedjen da je on uradjen po novinarskim profesionalnim standardima, a zapravo biva izložen propagandi, odnosno, brišu se granice izmedju oglasa i sadržaja teksta, pa je usled toga proizvedeno dejstvo pročitanog, daleko iznad klasičnog reklamiranja.

Amerikanci tvrde da prosečan TV gledalac u toj zemlji, može biti izložen dejstvu i do 3000 različitih reklamnih poruka dnevno! Jasno, tradicionalne TV reklame, lako se izbegavaju, prostim izborom nekog drugog programa; njihov najveći neprijatelj je daljinski upravljač.

Marketari iznalaze nove tehnike, okreću se novim medijima, u prvom redu Internet, ali i mobilna telefonija je sve više zastupljena. Novije generacije mobilnih aparata, android i " pametni " telefoni imaju pristup Internetu, tako da su danas, naročito mladi, na mreži prisutni više posredstvom svojih telefona, nego personalnih računara.

Internet je pogodan za plasman ovih sadržaja, posebno putem video - igrica, pojavljuju se logo oznake, oglasi, čak inkorporirani u sam scenario video igara.

Nadalje, otvaranje nekih Web stranica potražuje unos šifre ili ključne reči, pa tako se pojavljuju baneri sa oglasima, koje hteli ili ne, moramo videti, pa makar da nas to samo nervira, jer se otvara sadržaj koji nismo želeli.

Prikriveni marketing je, izmedju ostalog i "gerila- marketing", koncept jednostavnog prenosa informacija o proizvodu, na primer, na nekom blog sajtu, po sistemu: prijatelj kaže prijatelju o svom prijatelju koji je kupio proizvod prošle nedelje.....

Opravdano je pretpostaviti da će neko iz ovog lanca prijatelja, biti motivisan i inspirisan da kupi isto.

Konvencionalne reklame klasifikuju se kao "Above the line " - iznad linije, klasična propaganda koja na uobičajen način koristi medijski prosror.

Prikriveni marketing je klasifikovan kao " Below the line. " Ovaj marketing prenosi reklamne poruke tako da korisnik prosto nije svestan da je deo propagandne kampanje. Koriste se koncepti kao što je viralni marketing - prenos informacija socijalnim mrežama, zatim marketing iz zasede - propagiranje proizvoda na dogadjajima za koje nije plaćeno sponzorstvo ili drugi vid kompenzacije za propagandu, ali se ipak neočekivani oglašava (pojava zvana besplatna vožnja). Nadalje, može da se koristi sen- zacijski marketing, kreativni pristup sa ciljem da se izazove šok, senzacija kod potrošača. [5]

Da bi postigao planirano dejstvo, Stealth marketing mora imati učinak na veliki broj ljudi, i što je efekt iznenadjenja veći - to više ljudi biva upoznato sa porukom.

Inače Stealth marketing uključuje tri osnovna elementa:

- Efekt iznenadjenja

- Efekt rasprostranjenosti

- Niske troškove kampanje [6]

\section{Efekt iznenadjenja}

Osnovni princip Stealth tipa marketinga je iznenadjenje neočekivanim sadržajem, koji ima za cilj skretanje pažnje korisnika Interneta. Neobične poruke, nesvakidašnje, duhovite, šokantne čak i apsurdne, ostavljaju jači utisak, jednom reči sve ono što je neočekivano - bitno je emotivno pokrenuti posmatrača.

\section{Efekt rasprostranjenosti}

Cilj ovog elementa skrivenog marketinga je povećanje broja ljudi koji će videti marketinšku poruku. Internet daje gotovo neograničene mogućnosti, posebno pojavom društvenih mreža. Facebook je praćenjem aktivnosti preko " ticker" trejsera, otvorio mogućnost praćenja poslatih poruka. To je praktično elektronski sistem " od usta do usta " nivo poverenja u porukama i preporukama je veoma visok, jer medjusobno, direktno komuniciraju ljudi koji se znaju, imaju status prijatelja.

\section{Niski troškovi kampanje}

Broj korisnika Interneta u svetu, davno je premašio milijardu ljudi. Internet je postao sinonim globalizacije. Troškovi propagande na takvoj svetskoj mreži, u poredjenju sa klasičnim promotivnim tehnikama, su toliko niski, da slobodno možemo reći da gotovo ne postoje.

Skriveno oglašavanje ili Stealth marketing, često se vezuje za koncept subliminalnih poruka, odnosno sadržaja koji se ne mogu svesno opaziti, ali se percipiraju na nivou nesvesnog.

\section{SUBLIMINALNE PORUKE - SUBLIMINATI}

Da bi podražaj iz okruženja izazvao senzorni odgovor našeg organizma neophodno je da ima dva osnovna kvaliteta: da bude dovoljno jak, intezivan i dovoljno trajan, odnosno da su te vrednosti iznad apsolutnog praga opažaja - apsolutnog limena, / Apsolutni limen - najmanji intezitet podražaja potreban za svestan opažaj /.

"Kod subliminalnog istraživanja, prag je nivo podražaja kojeg ispitanik nije svestan, ne zna da je podražaj uopšte postojao." [7]

Podražaji čije su vrednosti ispod apsolutnog praga nazivaju se subliminalni podražaji, i njih nismo u stanju svesno da opazimo. Medjutim, iako nemamo svest o po- 
stojanju tih slabašnih signala, opažamo ih na podsvesnom nivou. Ovako prenete poruke kriju svojevrsnu opasnost, razum je zaobidjen još u fazi podražaja, i mi im se ne možemo suprotstaviti, ne prepoznajemo ih kao uljeze i doživljavamo kao svoje sopstvene. $\mathrm{ka}$ !

Ovo je ultimativna marketinška manipulativna tehni-

Zadnjih godina, razvojem neuromarketinga, nedvosmisleno je dokazano dejstvo ovako plasiranih sadržaja, čak i naredbodavnih.

\section{PRIKRIVENI MARKETING I ETIKA}

Pojam etika dolazi iz starogrčkog jezika od reči ethos koja je označavala običaj, naviku, karakter. Etika je filozofska disciplina koja se bavi ispitivanjem ciljeva i smisla moralnih delovanja i ponašanja. [8]

Moral kao univerzalna pojava, omogućava individualno diferenciranje ka iskonskoj dihotomiji izmedju dobra i zla. Profesor Čupić moral tumači i kao regulativnu ideju koja uspostavlja red, sigurnost i stabilnost. "Tamo gde većina ljudi prihvata i živi po moralnim pravilima, društvo je uredjenije, poredak stabilniji, a pojedinci sigurniji.“[9]

Govoreći o osnovnim principima opšte moralonosti

profesor Miljević ističe: "Opšta moralnost je skup moralnih načela koja regulišu uobičajene etičke probleme. Ovo su pravila po kojima većinom živimo i koja možemo da upotrebimo da bismo shvatili probleme menadžera u etičkom smislu." [10]

Zatim, navodi moralne principe; držanje obećanja, odsustvo zle volje, uzajamna pomoć, pojam solidarnosti, poštovanje ličnosti, poštovanje vlasništva. Za nas je, u ovom kontekstu, posebno značajan moralni princip poštovanja ličnosti.

"Opšta moralnost nam nalaže da posmatramo druge ljude kao cilj, a ne kao sredstvo za postizanje naših ciljeva. To podrazumeva da ih shvatamo ozbiljno, smatramo njihove interese legitimnim i prihvatamo da su njihove želje važne." [11]

\section{STEALTH MARKETING}

\section{Abstract:}

Internet propagation campaign that aims to generate a covert form of advertising, is economical, one raised in sufficient quantity, becomes almost free, it becomes recommended that the network is expanding. Hidden marketing can reach consumers who are isolated from other media, and unlike them, consumers tend to believe more in such facilities placed. When targeting known to be consistent users of the Internet, stealth marketers have a significant interest in using chat rooms, Face book, various blog sites and social forums. In these settings, people have a tendency to perceive each other as equals. Anonymity reduces the risk of detection so that a marketer can make an impact on a larger number of people. During the dot.com boom at the turn of the century promoters often use social media to create buzz (stealth) marketing.

The truth is that marketers can hardly predict the trends of development buzz propaganda. Well- placed, once launched, among consumers will begin to spread the story further, such as verbal techniques from mouth to mouth so initiating a planned viral marketing campaign, which will grow spontaneously. Financial risk is almost nonexistent because the cost is extremely low, and usually very fast and multiple payments. Undercover marketing is used when traditional techniques are exhausted, or advertise products which are inaccessible to conventional advertising streams. This remains an inexpensive, effective way to generate undercover marketing, especially in markets such as tobacco and alcohol where the media in order to protect consumers, not available as a form of advertising.

\section{Key words:}

Internet, propaganda, undercover marketing, Stealth (buzz).
Primena prikrivenog marketinga pokreće etičko pitanje emitovanih poruka jer krše osnovno načelo moralnosti - poštovanje ličnosti, baš iz razloga nedostatka svesti o - odnosno tako usvojeni sadržaji su namogućnosti prime zuzlo subjekta. Uopšte postojanje i niz kontroverzi i sukobe mišljenja stručne ali i ostale javnosti. Naš stav je da ljudi koji se bave marketingom, treba povuče jasnu liniju razgraničenja?

http:// librery.thinuquest.org/17360/text/tx-e pod.html,

htp.//doscdrive.com/pdf ajm/0000/2861 - 2861.pdf

[6] Chessman J. Merkile P. Priming with and without awerness, Perception and Psychophisics, 36, Vol. 4

[7] KimelA.JIntroduction:MarketingCommunication in the New Millenium. Marketing Communication - New approaches, Technologies and Styles, Oxford Univ. Press, 2005. p. 1 - 6

[8] [9] Čedomir Čupić, Etika i moral novinara, Fakultet političkih nauka, Beograd, Godišnjak 2008. str. 257

[10] [11] Milan Miljević, Poslovna etika i komuniciranje, Univerzitet Singidunum, Beograd, 2010. str. 226 str. 224 - 225 